\title{
A New Craze for Food: \\ Why is Ireland turning into a foodie nation?
}

Marjorie DELEUZE

(Trinity College Dublin / Université de Lille III, France)

As one observes the culinary scene of Ireland today, there is an impression of abundance, hedonism and hyperconsumption that pervades all food-related areas: Ireland has gone mad about food. There has been a profusion of cookbooks, of TV cooking programmes starring celebrity chefs as well as completely unknown figures. The numerous food festivals, farmers' markets, food blogs, food exhibitions, the eclectic restaurants to ravish the gourmets' cosmopolitan tastes, the explosion of food-oriented businesses have changed the face of modern Ireland. The Republic is definitely writing a new page in its culinary history and this new phenomenon cannot go unnoticed. Should this be regarded as a mere fashion trend within a wider global context, or as a real cultural, artistic and sociological revolution reflecting Ireland's current aspirations? How can we interpret these changes? In this paper, I will analyse the different reasons for this growing interest in food.

The interest in food in Ireland is not new, but it seemingly has reached a level never reached before. One could say that Ireland is turning into a foodie nation. But what does this mean exactly? The word 'foodie' was first coined in 1984 by Ann Barr and Paul Levy in The Official Foodie Handbook. They define 'foodies' as "children of the consumer boom [who] consider food to be an art, on a level with painting or drama. [...] Foodism crosses all boundaries and is understood in all languages. Food is the frontier to be on."(1984, p.6) As the book was intended to be a satire of its time, the word is pejoratively connoted when it characterises people with a rather snobbish and demanding attitude towards what they eat, or when worshipping of food and fetishism is at stake. Nowadays, the term has progressively lost its negative meaning. It has evolved in a more consensual and generic way. According to the Oxford Dictionary, a foodie is "a person with a particular interest in food or a gourmet". It is "a person having an enthusiastic interest in the preparation and the consumption of good food" for the Collins Dictionary. In short, as everyone has his own definition of what good food is, anyone can be a foodie today, it is no longer exclusively the preserve of the well-off. 
For a witness from outside, Ireland may seem to follow the trends of globalised societies. The Celtic Tiger era launched Ireland on the international scene. It is now commonly acknowledged that Ireland is a serious competitor in many sectors. Irish lifestyles more or less resemble those of Britain, France or the USA. With the economic boom, Ireland entered the age of hyperconsumption. As Gilles Lipovetsky explains: "In every domain there is a certain excessiveness, one that oversteps all limits. [...] The frenzied escalation of "more, always more' has now infiltered every sphere of collective life (2005, p.32)." As the philosopher asserts, hypermodern societies seek private pleasures before collective ones. They are societies of fashion worshipping the 'here-and-now' (2005, p.57). Technologies of ephemerality, of permanent seduction and of novelty such as the television or the Internet are predominant in our lives and entice populations to consume unrelentingly. Leisure and selffulfillment have been set up as a complete philosophy. In addition, in such societies, it is imperative to differentiate oneself from the other. Competition is fierce. Thus, social recognition and personal merit have been put on a pedestal. Individuals wish to participate in building history in their own way: the impressive number of cooking programmes, cookbooks, and other food blogs perfectly illustrates both the idea that everything converges towards the individual and that leisure is ardently pursued. This society of 'hyperchoice' is the perfect fertile ground for the emergence of foodies. In a sense, food is the ultimate expression of individuality. How is this conveyed in $21^{\text {st }}$ century Ireland? Given the context we have just set, in what measure has Ireland been transformed on the culinary scene?

Back in the 1950's when An Bord Fáilte was created, and for several decades afterwards, Ireland suffered from a very negative image in terms of gastronomy. The role played by the tourist board in promoting Irish food through the years has been huge, notably through brochures. In a brochure aimed at the French in 1974 we can read: "Ireland is certainly not the country of gastronomy. But there's no need to denigrate Irish cuisine as a whole...With modesty, we let, those who know, make complicated culinary preparations. What we serve is first and foremost simple" (Bord Fáilte, 1974, p.12). In 1987 in another brochure aimed again at the French, a more positive image is rendered: "It is obvious now, that over the last few years, Irish cuisine is getting better. Good restaurants are opening everywhere and for all pockets. Obviously, people are not coming for Irish cooking alone, but you never know... (1987a, p.IX)" This is really interesting when you know that today Fáilte Ireland is implementing measures to attract tourists to Ireland for an authentic and local food experience. 
Perhaps more than anything else, the development of catering, and particularly of restaurants, owes a lot to the tourist board. In the late fifties, visitors from abroad as well as Irish people who wished to dine out had to go to restaurants in large hotels. Very few individual restaurants existed at the time. As Josephine Mac Sorley pointed out in 1955, "the country is small and, except in the cities, the eating-out population is limited by the fact that everyone is within walking distance of his own home (Mac Sorley 1955, p.17)." For obvious economic - and perhaps religious - reasons, eating out had not yet become fashionable, it was only reserved for special occasions.

The seventies paved the way to gastronomic changes. Not only did the tourist board play a role in advertising Irish food assets, but it also contributed in the wings to changing people's opinion on the subject. In 1972, Bord Fáilte published its first Guide to Good Eating. In Bord Fáilte Review of 1978, we learn that "a major survey of dining-out requirements was undertaken to find out what tourists and home holiday makers look for in food and eating out facilities. The results were published in a booklet Thought for Food, Bord Fáilte and the Regional Tourism Organisations published a national guide Dining in Ireland covering 600 restaurants. A Dining in Dublin guide was also produced (1978, p.19)." The publication of guides soon had a major impact on the industry. Firstly, it was a reassuring mark of quality at the time. The popularity of guides such as the Bridgestone Guides proves it is still the case today. Secondly, emulation and a competitive desire to feature in the guides encouraged not only restaurant owners to give their best, but also motivated chefs and all the other actors in the sector. They might also have had the possibility of appearing in Ireland of the Welcomes as was the case of the Allen family who broke all the records of being written about. Today, chefs like Kevin Thornton, Darina Allen or Patrick Guilbaud are no longer strangers to the magazine's readers. In addition to the various guides, the Awards of Excellence scheme for restaurants was introduced in 1979. It was also the beginning of sponsorship in 1987, with Ballygowan Spring Water Company sponsoring the Dining in Ireland Awards of Excellence. The creation of Bord Bia in 1994 and its partnership with Bord Fáilte reinforced sponsoring throughout the country.

But most importantly, in 1988, "the Intoxicating Liquor Act [set] out, for the first time in the history of the State, a procedure for the full licensing of restaurants" (Seanad Éireann 1988). Designated as the only inspecting authority, Bord Fáilte was from that point on charged with the registration and grading of hotels, guesthouses and other forms of tourist accommodation (Seanad Éireann 1988). Predictably, as the Celtic Tiger cub was gaining 
strength, the number and the variety of restaurants consequently soared - more than 4000 today, with more than a quarter in Dublin.

In addition, Bord Fáilte's role in training and employment in the food sector, in partnership with the Institutes of Technology, greatly transformed the Irish culinary scene. In 2009, according to the website of the Restaurants Association of Ireland, restaurants employed about 64,000 people and the whole food-related business generated $€ 2$ billion for the Irish economy. The negative reviews Irish gastronomy used to receive are now a thing of the past. Ireland has now highly-qualified chefs and cooks thanks to continuous and strenuous efforts in training and education since the 1950's. CERT, a specialist recruitment and staff development organisation was set up at this time. Their mission was to "establish formal training for hotel and catering staff through specialised training centres" (Corr 2006, p.42). They were to work in partnership with Bord Fáilte for several decades before merging in 2003 into Fáilte Ireland, the National Tourism Development Authority. In 2011, given the economic turmoil, Fáilte Ireland drew up a new plan for food tourism businesses. Food was identified as a key pole of attraction for tourists: "Ireland will be recognised by visitors for the availability, quality and value of our local and regional food experiences evoking a unique sense of place, culture and hospitality" (Fáilte Ireland 2011a). The implementation of the 'place on a plate' concept is very successful and culinary tourism attracts more and more visitors.

And Irish tourists are no exception here. A recent survey (Fáilte Ireland 2007, pp1617) identifies three categories of home holiday makers. The first category, 'the Food and luxury seekers', forms about $20 \%$ of the domestic tourism demand. It mainly comprises urban-based couples aged 25-50, looking for rest and relaxation, week-ends away with good food and value for money. The second category, the 'Nightlifers', forms about $25 \%$ of the domestic tourism demand and is mainly made up of single people aged 18-35, looking for fun, good food, drink and entertainment and week-end breaks. The final category, the 'country ramblers', accounts for about $20 \%$ of domestic tourism demand and mainly comprises people over 50 looking for good deals, comfort and good food. So, it seems that $65 \%$ of Irish tourists want good food! These figures are significant, and help to understand why there is a noteworthy increase in popularity for culinary tourism and gastronomy. Several culinary centres are even about to be launched (Deegan 2011). It absolutely confirms the idea that Ireland is turning into a foodie nation.

As Masterchef Ireland winner Mary Carney declared in the Irish Times: "Food needs to do more than taste good, it also needs to tell a story. People want to connect to the food 
(Hunt 2011)." Another way Irish people like to connect with the food is by attending food and drink festivals. Taste of Dublin "the must-do foodie social event of the summer (A Taste of Ireland 2012)" first held in June 2006 expects 30,000 visitors in 2012 (Taste of Dublin 2012). Most of these festivals are quite recent, with the exception of the Galway International Oyster and Seafood Festival, and the Clarenbridge Oyster Festival running since 1954. The Galway Oyster Festival started with 34 guests and now welcomes around 10,000 each year. Overall, Fáilte Ireland has listed 47 food and drink festivals for 2012 alone. Besides, as an alternative way to visit Irish cities, food trails are now also offered to the curious and insatiable tourist or to the local foodie. But undoubtedly, the most popular venue among the foodies is the farmers' market. As stated on Bord Bia's website: "Farmers' Markets in Ireland have experienced considerable growth in recent years with fewer than 100 markets in 2006 and almost 150 currently in existence throughout Ireland. With unemployment on the increase, consumers are certainly keen to support local jobs and with producers usually manning stalls themselves, a farmers' market is perhaps the most tangible way for them to do this." (Bord Bia 2012) Farmers' markets and country markets especially appeal to the consumers because they are in direct contact with the local producers, it gives a more humane approach to shopping, dialogue is possible and it is probably more reassuring to associate a face with a product. It is a highly-valued guarantee of quality.

Among other experiences available to the foodie, classes in cookery schools enable anyone to become a chef for a day, or even to obtain a Certificate within a few weeks if they wish to go professional. It is commonly accepted that to become a professional cook in Ireland, you either study in an Institute of Technology or take a course in one of the most renowned cookery schools such as the Ballymaloe Cookery school. As specified on the Tannery website, a course in a cookery school is "an ideal getaway for a foodie". Foodism in Ireland takes many other forms: the Food and Wine magazine has its readership evaluated at almost 67,000, Easy Food encounters a staggering 15\% increase in sales each year - its readership is evaluated at more than 110,000 (Magazine Ireland 2012). It goes without saying that British magazines (BBC Good Food, Jamie Magazine) cover a fair share of the market as well. We could also mention the food blogs which are the new trendy way for foodies to express their passion. According to the young TV presenter Donal Skehan, who became notoriously famous thanks to his food blog, there were 15 members in the Irish food blogging community in 2007 (Digby 2012), they are now more than 500. The Irish Food Bloggers Association was set up in 2010 in order to respond to the need to create a community of foodies via a platform of exchange (Irish Food Bloggers Association 2012). Another way for 
food fans to share their passion and exchange their views is to attend events such as cookbook club meetings. The Dublin-based association meets monthly at the Radisson Blu Hotel where the kitchen team recreates recipes from a famous chef's cookbook. So far, chefs such as Derry Clarke, Clodagh McKenna or Kevin Dundon have been invited to present their books. We have already mentioned the food and drink festivals as the ultimate foodie event, but more scientific or academic gatherings seem to attract many people as well. In February 2012, the Science Gallery launched Edible: the Taste of Things to Come, the first exhibition of this kind in Ireland. With a giant inflatable stomach on display, quirky dining experiences and conferences, the aim was to "focus on actual eating and the role of the eater (Mullally 2012)" as well as making people reflect upon ecological implications of how and what they eat. In September 2011, both the Alliance Française and the Dublin Institute of Technology received the French scientist Hervé This, co-founder of 'molecular gastronomy', for lectures on his research. In April 2011, the Institute of Technology Tallaght organised their first Gastronomy Research Day. The effervescence surrounding the Inaugural Dublin Gastronomy Symposium, hosted by the Dublin Institute of Technology in June 2012, proves once again that food can bring together many food enthusiasts from very different horizons.

The list of possibilities for a foodie to satisfy his or her voracious appetite of knowledge is thus endless, but the most popular and traditional method is undeniably a quite solitary one: through cookbooks and TV cooking programmes. For RTÉ alone, from Monica Sheridan in 1963 to the plethora of Irish and British chefs of today, the broadcasting of culinary shows has progressively increased to not less than an average of 10 hours a week. To name a few: Masterchef, The Restaurant, Catherine's Italian Kitchen, Paul Flynn: Irish Food, Fresh from the Sea, Kitchen Hero, Come Dine with me, Martin's Mad about fish, Aingeal sa Chistin, Bean an Tí sa Chistin, plus all the programmes available on British channels. For some, the centre of gravity of an interest in food has been shifted from the kitchen to the living-room! This successful food-entertainment revolution has the primary function of making people dream of a different lifestyle, of helping them escape from their daily routine. The second function is to educate by way of more environmental-centred debates. In 2011, The Restaurant scored the biggest audience figures with 315,000 viewers, it was followed by Neven Maguire: Home Chef with 315,000 viewers and Kitchen Hero with 289,000 viewers (Gittens 2011). Surprisingly enough, the programmes starring female chefs were not the most popular ones.

As regards cookbooks, a simple stroll through any bookshop will tell you that it is a hugely profitable and dynamic market in Ireland today. Irish cookbooks, ethnic cookbooks, 
cookbooks written by the most renowned French chefs (or by any passionate foodie who has never spent a day in a professional kitchen), Modernist Cuisine cookbooks, or old grannystyle cookbooks re-printed such as Maura Laverty's Full and Plenty, show that the era of 'hyperchoice' is definitely here! How did these changes occur? How come Irish people got so enthralled by what had long been considered a peripheral matter?

Eating, tasting, sharing food, showcasing food, talking about food, playing the sorcerer's apprentice with food, reading about food, exhibiting it like a scientific object of curiosity, beyond its mere survival properties, the scope of possibilities seems infinite. Our relation to food expresses many things about oneself. Although, in spite of its uncontested character, Brillat-Savarin's old adage "Tell me what you eat and I will tell you who you are (1982)" should be slightly modified and given a modern twist. Undoubtedly, it lacks the idea that human beings are first and foremost defined by the way they treat, regard and prepare food, then by the way they eat. Mirror of our soul, our creeds, our philosophy, our states of mind, the rituals of cooking and eating perpetually evolve, so does the society we live in. Long gone is the time when Monica Sheridan licking her fingers on TV would shock her audience. And this takes us to our next point: is a more liberal and secular society a possible reason for the success all food-related subjects are encountering today?

Undoubtedly, this 'foodie' phenomenon is not just happening in Ireland, it is a global trend that is due to a whole array of external influences. The interest here lies in the fact that the reasons why it developed in such a way are specific to the Republic of Ireland. Let's put things into context. Religion in Ireland is clearly losing ground. If over 84\% of the Irish population claims to be Roman Catholic (according to the 2011 census), numbers have shrunk dramatically on church benches every Sunday morning. What has really changed is people's attitude towards morality and obedience to the Church. Thus, principles such as fasting, privation, gluttony and other matters of the flesh have acquired a totally different meaning. Children do not fear God's wrath anymore if they have swallowed a few sweets during Lent. For the same reason, fish is no longer reserved for fast days. The way people regard their body has also significantly evolved. Very often cookery programmes are redolent with a sensuality that would have been unbearable for a viewer in the 1960's. Censorship was diligent enough to prevent this from happening anyway. The link between the body and food, as opposed to spiritual matters, has endured for centuries. The act of concupiscence, stemming from Adam and Eve not resisting temptation and eating an apple, designates man's natural inclination to sin. This is why excess of food and rich foods have long been associated with the deadly sin of gluttony. Beginning in the 1970's, the relaxation of moral standards 
would actually pave the way for a different approach to food. Not only did Paul Levy coin the term 'foodie' but he also coined the word 'gastroporn' (1984, p.102). It means that food is staged and photographed like an eroticized body, supposedly to seduce the eater. Today, the correlation between food and seduction is extensively used in the marketing of many products. The pleasure of the senses is promoted. In television cookery programmes, we encounter comments such as "visually it looks so inviting", "your food is just sexy", or "if you weren't married, I'll be cooking with you tonight" (Masterchef Ireland 2011).

As mentioned previously, Monica Sheridan, with her funny and impertinent wit, dominated the culinary scene in the 1960's. As the first ever celebrity cook in Ireland, Ms. Sheridan broadened the Irish housewife's horizon. Irish women undoubtedly owe her a great deal as regards the evolution of their role in society. In the column she wrote for the Irish Times from May 1954 entitled "Good Cooking", she described her various experiences in France, travelling back and forth between haute cuisine restaurants and remote farms. She gave practical and modern advice to the Irish woman on how to organise her household. Cooking took a new dimension. Significantly enough, her first television programme, Monica Sheridan's Kitchen, was broadcast in 1963 on RTÉ at 6.15 pm. The following year, Monica Sheridan On Cooking was broadcast an hour later. Why did the time change? Women had written to the Irish Times to complain that at 6.15 they were still bathing or feeding their children and could not watch the show! Her popularity clearly exceeded the channel's expectations. And still today, many women recall with fondness her programmes and cherish her cookbooks like little treasures preciously nestled between Jamie's Oliver Naked Chef and Rachel Allen's Easy Meals. This invitation to travel, to discover new cuisines, different lifestyles, was not only reinforced by the cookbooks of British author Elizabeth David, but also by the growing popularity of holidays abroad. Irish people tried new ingredients, their palates started to be educated to more exotic foods. Surely enough, immigration also played its role. Today the big-city dwellers can eat in a great variety of ethnic dining-venues: Moroccan, Indian, French, Italian, Japanese or even Tibetan restaurants belong to the Irish urban landscape. In some areas it is even easier to find an Indian or a Polish grocery shop than a fishmonger. Thus, Asia Market in Drury Street and Eurasia supermarket on Fonthill Road primarily serve the ethnic community, but they also offer Irish people the possibility of experimenting on culinary trips with access to an array of produce completely unknown a few years back.

In addition, despite the fact that Ireland is deep in economic downturn, food-related businesses are absolutely thriving. Some even see the food industry as the solution to 
Ireland's problems. Every day, newspapers enthusiastically relate success stories of Irish food industries. To name just a few, Cully \& Sully has just been acquired by a big American organic food group; the newly open café-bakery Brother Hubard on Capel Street is already facing long queues at lunch times. Recent research led by Good Food Ireland and Grant Thorton assumes that food is "the secret ingredient to Irish tourism and export growth." It shows that two out of three Good Food Ireland-approved providers met earning expectations in 2011, and that 4 out of 5 expect growth in 2012 (Business ETC 2012). According to Suzanne Lynch of the Irish Times, "food and drink exports increased by 12 per cent last year, reaching close to $€ 9$ billion. [...] Irish agriculture embodies what is hoped will be the twin catalysts for the Irish economic recovery - exports and innovation (Lynch 2012)". It is also Philip Boucher-Hayes' opinion. He concludes in his provocative Basket Case by saying that "Irish food is a world-beating product. If [Irish food producers] are given better levels of support, there is enormous potential to exploit our natural resources and expertise in farming and food (2010, p.236)." So, yes, Ireland is a foodie nation, and it has to be so in the whole population's interest.

Besides, and that is one of the many contradictions of our hypermodern society, in reaction against the not-always-fair policies led by the all-powerful supermarkets, the foodie of contemporary Ireland has a more respectful, a more environmental and a more sustainable approach to food. The economic recession has upset and transformed people's views on life. The 'culchie' attitude, despised for so long, seems to be back. Darina Allen, and Myrtle Allen before her, have been constantly fighting for this 'place on a plate' concept. Local produce enabling producers to live from their land, in a sustainable manner, is a growing trend in Ireland, and this is probably for the best. Many local producers now belong to the Slow Food movement, founded upon the concept of eco-gastronomy and the aim of which is to "counteract fast food life, the disappearance of local food traditions and people's dwindling interest in the food they eat, where it comes from, how it tastes and how our food choices affect the rest of the world (Slow Food Ireland 2012)." From land to fork, with a minimum of distance between the two, is the message delivered on TV and on the ground by people like Richard Corrigan or Clodagh McKenna. The popularity of farmers' markets and local food festivals reinforces the idea that what people are looking for is literally to taste the place. Preserving what we call in French 'terroir', is unquestionably the struggle to preserve one's identity from galloping globalisation which erases all the little charms specific to each country. 
Freed from constraining religious principles, more open to other societies and exoticism, ready to experiment more adventurous dishes, Ireland has seen an unprecedented interest in food in recent years. In addition, the media and the Internet allow both a fast exchange of information and knowledge, and virtual culinary trips. Food becomes an object of fantasy in the same way we view the hero of a novel or of a movie. As regards the economy, tourism and the food industry have clearly understood that they have to work hand-in-hand to promote Irish food. Far from the hectic cities, Ireland conveys an image of wonderful, lush green pastures, of a fertile land full of quality produce. Moreover, in order to oppose the dehumanisation process engendered by global exchanges and by the 'macdonaldisation' of our hypermodern societies, foodism is expressed through a more environmental awareness and through the desire to protect and promote Ireland's food heritage. Ireland has definitely turned into a foodie nation, but has also developed on a more reflective and responsible attitude towards food. Although, let us not forget that for some people, food still equals survival and that not everyone is educated to what good food is, nor to the importance of regular and structured meals. The term 'foodie' still predominantly characterises food enthusiasts from middle-upper class. Not everyone can experience dining-out on a regular basis, not everyone can buy an entry to the Taste of Dublin - even if a recession-friendly ticket has been implemented this year -, and the farmers' markets are not really frequented by low-income people. In 2010, one in five children had reported going to bed hungry because of the lack of food in their household (Kennedy 2012). In order to overcome the realities of deprivation, foodies of another type emerge. Many wonderful initiatives have come from the less affluent areas. Crosscare's food bank was implemented twenty years ago; since then many 'Community Food Initiatives' have flourished. They are "projects to improve the availability, affordability and accessibility of healthy food for low income groups at local level using a community development approach (Healthy Food for All 2012).” Examples of such initiatives are food co-operatives, community food-growing projects in communal allotments, breakfast clubs in community cafés, educational projects ('Cook it!' programme, 'Healthy Food Made Easy' funded by the HSE) and many others. Food must be available to anyone, especially in a country endowed with so much high-quality produce. 


\section{Bibliography \& Webography}

Barr,A \& Levy, P. (1984) The Official Foodie Handbook: Be Modern, Worship Food. London: Ebury Press. Bord Fáilte (1974) Irlande. Dublin: Bord Fáilte.

(1978) Bord Fáilte Review of 1978. Dublin: Bord Fáilte. (1987a) Irlande. Dublin: Bord Fáilte.

(1987b) Reports and Accounts for the year ended $31^{\text {st }}$ Dec 1987. Dublin: Bord Fáilte.

Boucher-Hayes,P. \& Campbell,S. (2010) Basket Case: What's Happening to Ireland's Food? Dublin: Gill\&Macmillan.

Brillat-Savarin, A. (1982) Physiologie du goût. Paris : Flammarion - Champs classiques.

Corr, F. (2006) 'Training for Tourism', Ireland of the Welcomes, Vol.55, n5, Sept-Oct. 2006.

Deegan, G. (2011) 'Culinary visitor centre planned for Meath', The Irish Times, November 26, 2011.

Digby, M.C. (2012) 'Food File', The Irish Times, May 5, 2012.

Fáilte Ireland. (2007) Fáilte Ireland National Tourism Development Authority, Tourism Product Development Strategy, 2007-2013, Dublin: Fáilte Ireland.

(2011a) National Tourism Implementation Framework 2011-2013, available:

http://www.failteireland.ie/FailteCorp/media/FailteIreland/documents/Business\%20Supports/Tourism\%20Sector \%20Development/Food/49993_FailteIreland_Strategy.pdf

(2011b) Your Guide to Fáilte Ireland Services 2011, available:

http://www.failteireland.ie/Information-Centre/Publications/Corporate-

Documents/Corporate/2011_Your_Guide_to_FI_Services

Gittens, G. (2011) 'Neven's flavour of the year as top TV chef', Herald.ie, December 13, 2011. Available:

http://www.herald.ie/news/nevens-flavour-of-the-year-as-top-tv-chef-2961721.html

Hunt, J. (2011) 'Producers urged to tell the story of their brand', The Irish Times, November 23, 2011.

Kennedy, S. (2012) 'Time to revive poverty agency', The Irish Times, May 5, 2012.

Lipovetsky, G. (2005) Hypermodern Times. Cambridge: Polity Press.

Lynch, S. (2012) 'Ireland reaping the rewards as agri-food industry keeps growing', The Irish Times, April 20, 2012.

Mac Sorley,J. (1955) 'Eating in Ireland', Ireland of the Welcomes, Vol.4, n², Sept-Oct. 1955.

Masterchef Ireland (2011) RTÉ One. Nick Munier was adressing Mary Carney in the 9th episode.

Mullally, U. (2012) 'You are what you eat', The Irish Times, February 4, 2012.

Seanad Éireann - Volume 120 - 28 June, 1988. Available:

http://historical-debates.oireachtas.ie/S/0120/S.0120.198806280010.html

A Taste of Ireland website, available: http://atasteof-ireland.com/2012/04/20/food-festivals-ireland-2012/

Bord Bia website, available:

http://www.bordbia.ie/aboutfood/farmersmarkets/pages/goodpracticeforfarmersmarkets.aspx

Business ETC website, available: http://businessetc.thejournal.ie/food-sector-pivotal-in-irish-tourism-426617-

Apr2012/

Collins Dictionary online, available: http://www.collinsdictionary.com/dictionary/english/foodie 
Healthy Food for All website, available: http://www.healthyfoodforall.com/what_is_a_cfi.htm Irish Food Bloggers Association website, available: http://www.irishfoodbloggers.com/about/ Magazine Ireland website, available: http://www.magazinesireland.ie/

Oxford Dictionary online, available: http://oxforddictionaries.com/definition/foodie?q=foodie

Restaurants Association of Ireland website, available: http://www.rai.ie/

Slow Food Ireland website, available: http://www.slowfoodireland.com/index.php/slow-food/what-is-slowfood.html

Tannery website, available: http://www.tannery.ie/classes.html

Taste of Dublin website, available: http://www.tasteofdublin.ie/exhibitors/why-choose-taste-2/

The Cook Book Club website, available: http://www.thecookbookclub.com/ 